\title{
The Effect of the Use of PTFE as a Covered-Electrode Binder on Metal Transfer
}

\author{
Cláudio Turani Vaz ${ }^{1,2}$, Alexandre Queiroz Bracarense ${ }^{2}$ \\ 1 Departamento de Engenharia de Materiais, Centro Federal de Educação Tecnológica de Minas Gerais - CEFET MG, \\ Belo Horizonte, MG, Brazil. \\ 2 Departamento de Engenharia Mecânica, Universidade Federal de Minas Gerais - UFMG, Belo Horizonte, MG, Brazil.
}

Received: 08 Apr., 2015

Accepted: 02 June, 2015

E-mail: claudioturani@gmail.com (CTV)

\begin{abstract}
Studies have shown that when used as binders for basic covered electrodes, polymers produce a weld metal microstructure with a high acicular ferrite content. The reasons identified for this behavior include changes in the shielding atmosphere and metal transfer mode. To investigate the effect of polymers on metal transfer, voltage oscillograms and high-speed films were recorded during welding with standard-binder and polymer-binder E7018 electrodes using different welding currents. Electrodes tips collected after the arc had been abruptly interrupted were examined metallographically. For electrodes with a polymer binder, the short-circuit frequency was lower regardless of the welding current used and decreased as welding current increased. In many events characterized as short circuits in the voltage oscillograms for polymer-binder electrodes, metal transfer in fact occurred without any arc interruption. The angle between the outer edge of the metal drop and the inner edge of the coating crater showed that the polymer increased the intensity of the plasma jet, and the pinch effect observed during welding using the polymer-binder electrode indicated that there were changes in surface tension and electromagnetic force.
\end{abstract}

Key-words: Polymer; Covered electrodes; Metal transfer.

\section{A Influência do Emprego de PTFE como Aglomerante em Eletrodos Revestidos sobre a Transferência Metálica}

Resumo: Estudos mostraram que o emprego de polímero como aglomerante em eletrodos revestidos básicos produz metais de solda com microestrutura diferenciada com elevadas frações volumétricas de ferrita acicular. Entre as causas apontadas para esse comportamento estão as alterações na atmosfera protetora e no modo de transferência metálica. Para investigar o efeito do polímero sobre a transferência metálica foi realizado o monitoramento da tensão e filmagens em alta velocidade durante a soldagem com eletrodos classe E7018 e aglomerados com polímero empregando diferentes intensidades de corrente. Pontas de eletrodos coletadas após a interrupção abrupta da soldagem foram submetidas a análise através de técnicas metalográficas. Independentemente da corrente empregada durante a soldagem foi observada uma menor frequência de curtos circuitos para o eletrodo com polímero. Para este consumível foi observado ainda a redução da frequência de curtos com o aumento da corrente de soldagem. Em inúmeros eventos caracterizados como sendo curtos circuitos pelos oscilogramas de tensão gerados na soldagem do eletrodo com polímero houve transferência sem a interrupção do arco elétrico. Notou-se, pelo ângulo entre a gota formada e o cone de revestimento, que o emprego do polímero intensificou o jato de plasma. Adicionalmente, o fenômeno de estrangulamento da gota formada observado na soldagem com este eletrodo, indica alterações na tensão superficial e força eletromagnética.

Palavras-chave: Polímero; Eletrodos revestidos; Transferência metálica.

\section{Introduction}

The production of consumables that have improved performance regardless of the welding process used is very closely related to the development and use of new raw materials. Bonizewski [1], in the third of a series of articles on welding with coated electrodes, reports that there has been a change in the profile of researchers who develop welding consumables and discusses new solutions for, and challenges associated with, low-hydrogen-content consumables. In an effort to increase moisture resistance, Sorokin [2] investigated the use of various types of polymers as binders in coated electrodes. The study described the resulting changes in the shielding atmosphere and their effect on the transfer of alloying elements to the weld metal but did not investigate whether
This is an Open Access article distributed under the terms of the Creative Commons Attribution Non-Commercial License which permits unrestricted non-commercial use, distribution, and reproduction in any medium provided the original work is properly cited. 
consumables produced in this way could be used in practice. Vaz et al. [3] in turn described the development of basic polymer-binder coated electrodes and investigated their performance. Their findings indicated that for the conditions tested the resulting weld metals had extremely low diffusible hydrogen content and a microstructure consisting of high volume fractions of acicular ferrite. Studying the influence of PTFE (polytetrafluoroethylene) on weld-metal microstructure, Vaz and Bracarense [4] attributed the increased volume fraction of acicular ferrite to the low nitrogen content observed in the weld metal. Investigating the causes of this phenomenon, they reported that the use of PTFE favors the formation of a more effective shielding atmosphere and changes in metal-transfer mode.

Brandi et al [5], investigating metal transfer in welding with coated electrodes, described the different experimental techniques used and their advantages and limitations. By depositing metal drops on a rotating copper disk, they investigated the effect of weld parameters on metal transfer for different types of electrodes. Their findings indicated that the predominant metal-transfer modes with the coated electrodes they studied were explosive, short-circuit and slag-guided. This conclusion was based on the physical characteristics of the drops. Chen et al [6] monitored metal transfer using different techniques based on measurement of arc force, surface tension and drop size and compared the results. Based on their findings, they suggested that globular metal transfer was the predominant metal-transfer mode.

According to Lancaster [7], in a review of studies of metal transfer in welding with coated electrodes, this phenomenon is a result of the action of forces associated with the pinch effect, surface tension, gravity, pressure at the cathode point, the flow of gases from the coating and the formation of gas bubbles inside the drop formed at the electrode tip. In his description of the mechanisms by which the slag and metal interact, Lancaster [8] notes that the interaction starts at the junction of the coating crater and liquid metal. The liquid metal is subjected to intense shaking as a result of electromagnetic forces and the drag caused by the gases given off by the coating, as a result of which the metal drop formed becomes homogeneous. Chen et al [6] concluded that surface tension and the force of the arc are the major factors responsible for metal transfer in welding with coated electrodes.

The main aim of this study was to investigate how a PTFE binder in basic coated electrodes affects metal transfer during welding. For this purpose, experiments were carried out with class E7018 electrodes with silicate and polymer binders Welding voltage was monitored for different currents to investigate how current influenced metal transfer. High-speed films were recorded using a combination of optimal parameters for both types of consumable. Macrographic techniques were used to investigate any differences in the way that drops were formed with each type of electrode. The results were used to prepare a physical model illustrating the effect of PTFE on metal transfer.

\section{Material and Methods}

\subsection{Consumables}

The experiments were carried out with $3.25 \times 350 \mathrm{~mm}$ PTFE-binder E7018 coated electrodes manufactured according to the formula shown in Table 1 and silicate-binder E7018 coated electrodes with the same dimensions. This comparison was only possible because these consumables have the same basic formula. All the welds were made on $12.7 \times 60 \times 250 \mathrm{~mm}$ ASTM A36 plate steel.

Table 1. Formula of the polymer-binder electrode coating.

\begin{tabular}{cc}
\hline Raw material & Quantity (\%) \\
Limestone & 24 \\
Iron powder & 23 \\
Fluorite & 12 \\
Polymer & 11 \\
Silicate & 9 \\
Ferrosilicon & 6 \\
Ferromanganese & 5 \\
Rutile & 4 \\
Feldspar & 3 \\
Others & 3 \\
\hline
\end{tabular}




\subsection{Equipment}

Welds were made using the mechanical device shown in Figure 1, which allowed the angle of attack and guide-rod angle to be adjusted. This was done in order to minimize any variations that might be produced by manual operation. The welds were produced with a Kemppi AC/DC 2500W Mastertig welding machine with a $100 \%$ duty cycle at $200 \mathrm{~A}$.

\subsection{Experiments}

\subsubsection{Voltage and current monitoring}

Welding voltage and current were monitored during weld bead deposition with the consumables and parameters described in Table 2. The data acquisition system used is shown in Figure 2. Data were collected at a sampling rate of 100 points/s and then processed with the Sinal program and used to produce oscillograms. The program was also used to take measurements such as the mean short-circuit frequency.

\subsubsection{High-speed filming}

Welds made with silicate-binder and polymer-binder E7018 electrodes using a $110 \mathrm{~A}$ current and $60^{\circ}$ angle of attack were filmed using an Olympus Encore MAC S camera at an acquisition rate of 500 frames/s. Welding with coated electrodes leads to certain difficulties when collecting and interpreting the images generated. To overcome these, the lenses were changed and the camera was adjusted and its position changed during the tests. Figure 3 shows the positions used for filming. The images generated were viewed at 5 frames/s so that metal transfer could be observed and analyzed. The number of short circuits was counted and the results were compared with those obtained from the oscillograms.

\subsection{Macrographic and micrographic assessment of the electrode tips}

The tips of the silicate-binder and polymer-binder electrodes were removed for examination after welding was abruptly interrupted after $30 \mathrm{~s}$. Samples consisting of electrode core alone and electrode core and coating were cold mounted in epoxy resin, sanded, polished and etched with $5 \%$ nital so that the cross sections could be examined macrographically and micrographically with stereoscopic and optical microscopes at different magnifications.

\section{Results and Discussion}

Figures 4 and 5 show $10 \mathrm{~s}$ segments of voltage oscillograms for welds made with the standard-binder and polymer-binder electrodes, respectively, using different

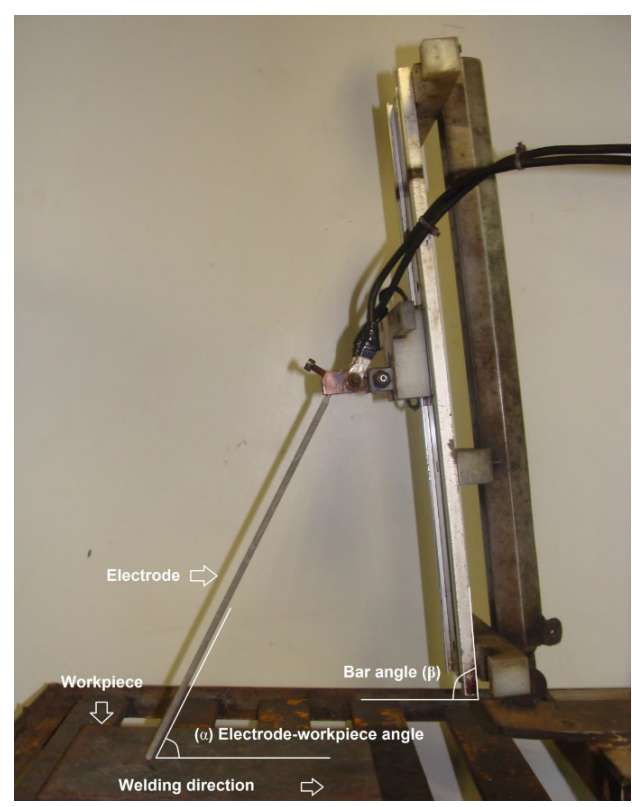

Figure 1. Device used to automate welding operations.

Table 2. Welding parameters used during voltage and current monitoring.

\begin{tabular}{|c|c|c|}
\hline Electrode & $\begin{array}{c}\text { Angle of } \\
\text { attack (a) }\end{array}$ & $\begin{array}{c}\text { Current } \\
\text { (A) }\end{array}$ \\
\hline $\begin{array}{c}\text { Silicate-binder } \\
\text { Polymer- } \\
\text { binder }\end{array}$ & $60^{\circ}$ & $\begin{array}{c}90 \\
110 \\
130\end{array}$ \\
\hline
\end{tabular}

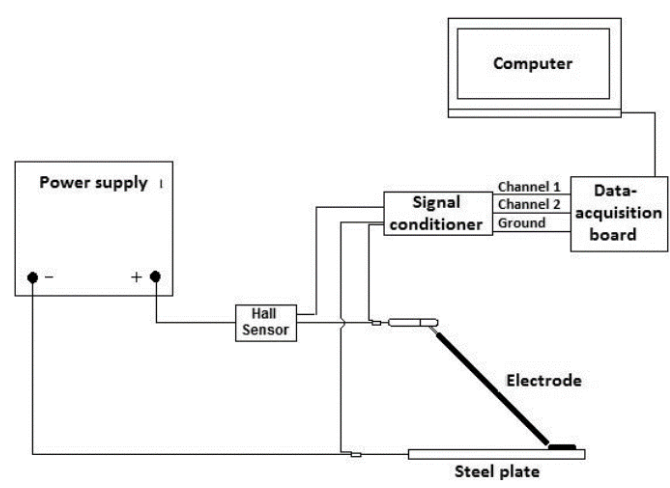

Figure 2. Schematic representation of the system used to monitor welding voltage and current.

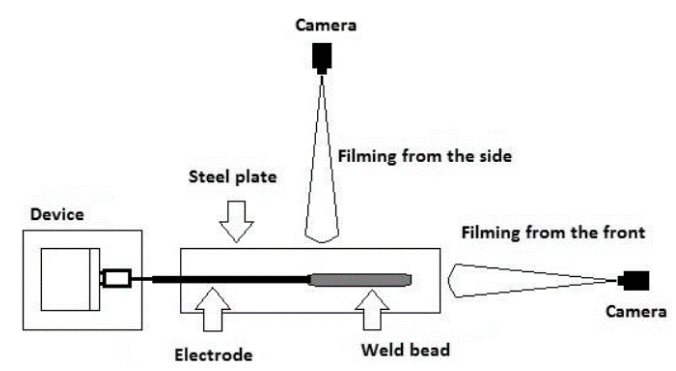

Figure 3. Different camera positions seen from above. 
currents. For the electrode with the polymer binder (Figure 5), an increase in current leads to a reduction in the number of short circuits; at a current of $130 \mathrm{~A}$ this reduction is particularly marked. This behavior is not observed when the silicate-binder electrode is used (Figure 4). To confirm this trend, the mean short-circuit frequencies were calculated with the Sinal program. These are shown in Figure 6 together with the measurement uncertainty for a confidence interval of $95 \%$. For the polymer-binder electrode, the short-circuit frequency reduces with increasing
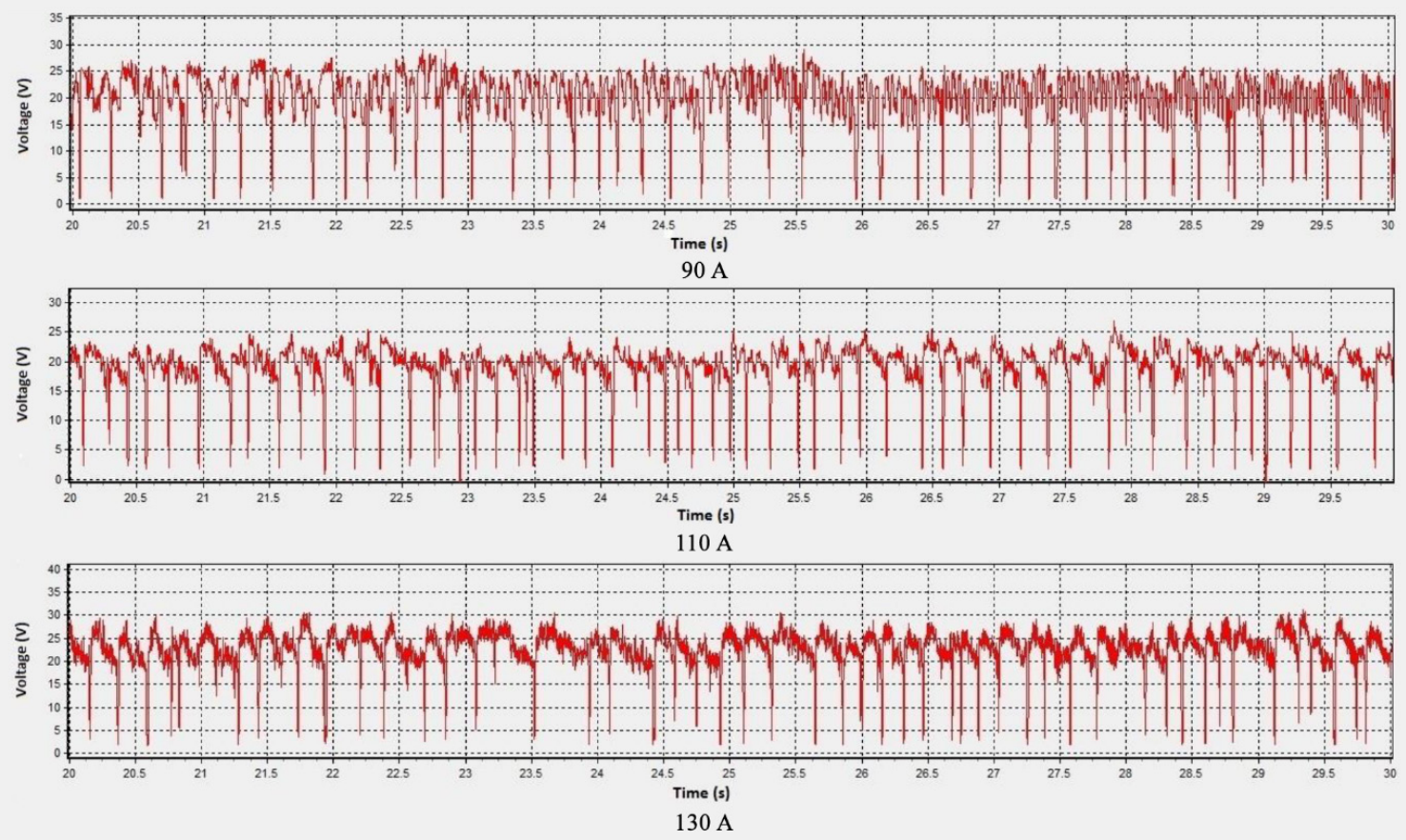

Figure 4. Typical voltage oscillograms produced during welding with a silicate-binder electrode using different currents (10 s monitoring period).
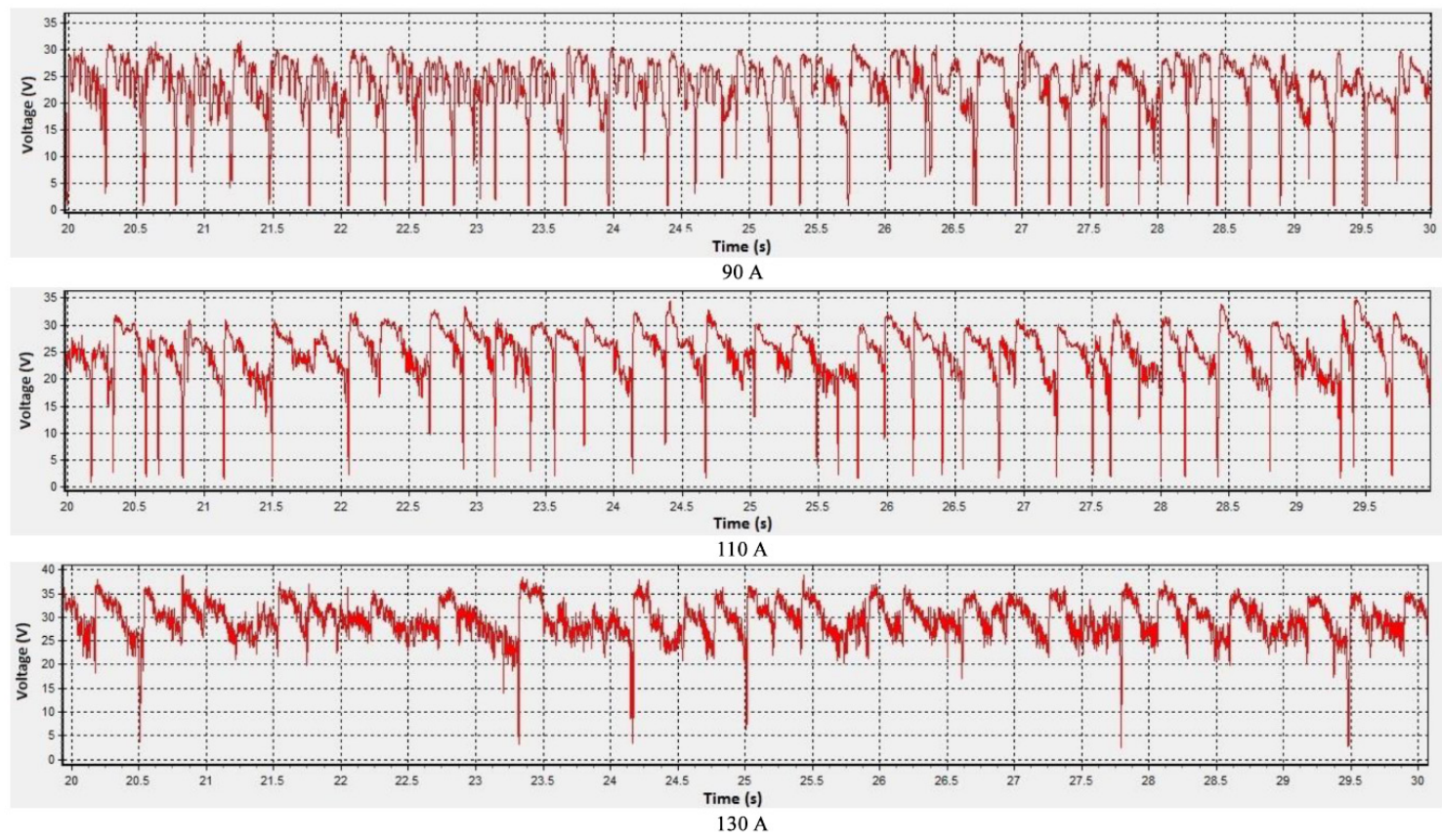

Figure 5. Typical voltage oscillograms produced during welding with a polymer-binder electrode using different currents (10 s monitoring period). 
current. Although this trend can also be observed for the silicate-binder electrode, the variation in this case is within the measurement uncertainty. Figure 6 also shows that the short-circuit frequency for the polymer-binder electrode is lower than the short-circuit frequency for the silicate-binder electrode regardless of the current used.

With the exception of the weld produced with the polymer-binder electrode using a current of $130 \mathrm{~A}$, visual analysis of the weld beads (Figure 7) failed to reveal significant differences. With a current of 130A, there was a significant increase in spatter. Comparison of this result with the oscillogram for these conditions lends weight to the hypothesis that the metal-transfer mode changes from short circuit to another mode that could, in principle, be explosive transfer. The sequence of frames in the high-speed recording shown in Figure 8 is consistent with this hypothesis as spatter occurs without any interruption of the electric arc.

In light of these results, further experiments were carried out using a nominal current of $110 \mathrm{~A}$ with both consumables to investigate the influence of the polymer on metal transfer. While side images of the arc did not allow the characteristics of the metal transfer to be identified, images of the front of the arc showed the drops forming and detaching from the electrode. Figures 9 and 10 show the sequences illustrating this phenomenon during welding with both the electrodes studied here. With the silicate-binder electrode (Figure 9), a drop forms and grows and is then transferred during a short circuit. When a polymer-binder electrode is used (Figure 10), the drops form and are transferred without the electric arc being interrupted. This phenomenon was observed frequently with this consumable.

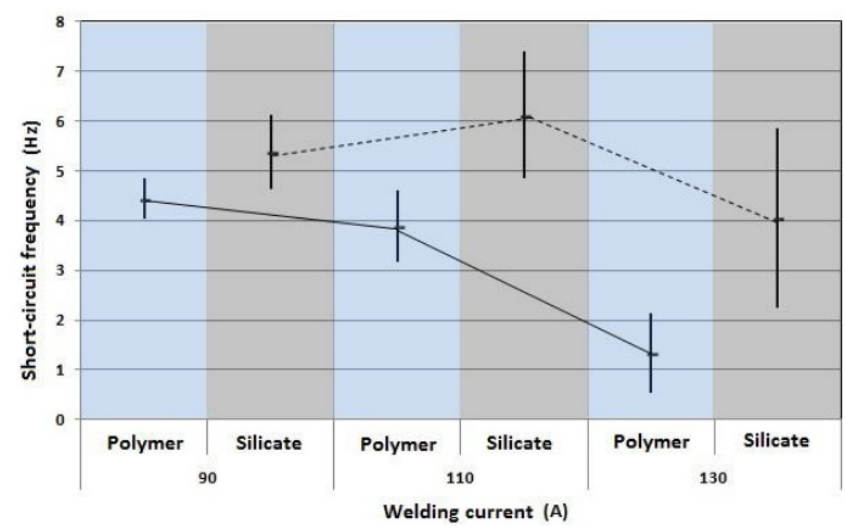

Figure 6. Short-circuit frequency as a function of current for polymer-binder and silicate-binder electrodes; $95 \%$ confidence interval.

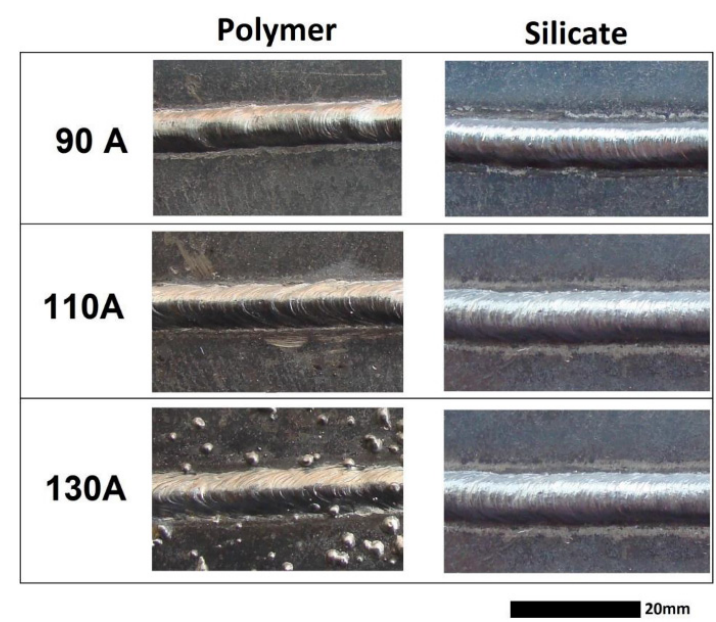

Figure 7. Weld beads produced with the two types of electrode at currents of 90,110 and $130 \mathrm{~A}$. 

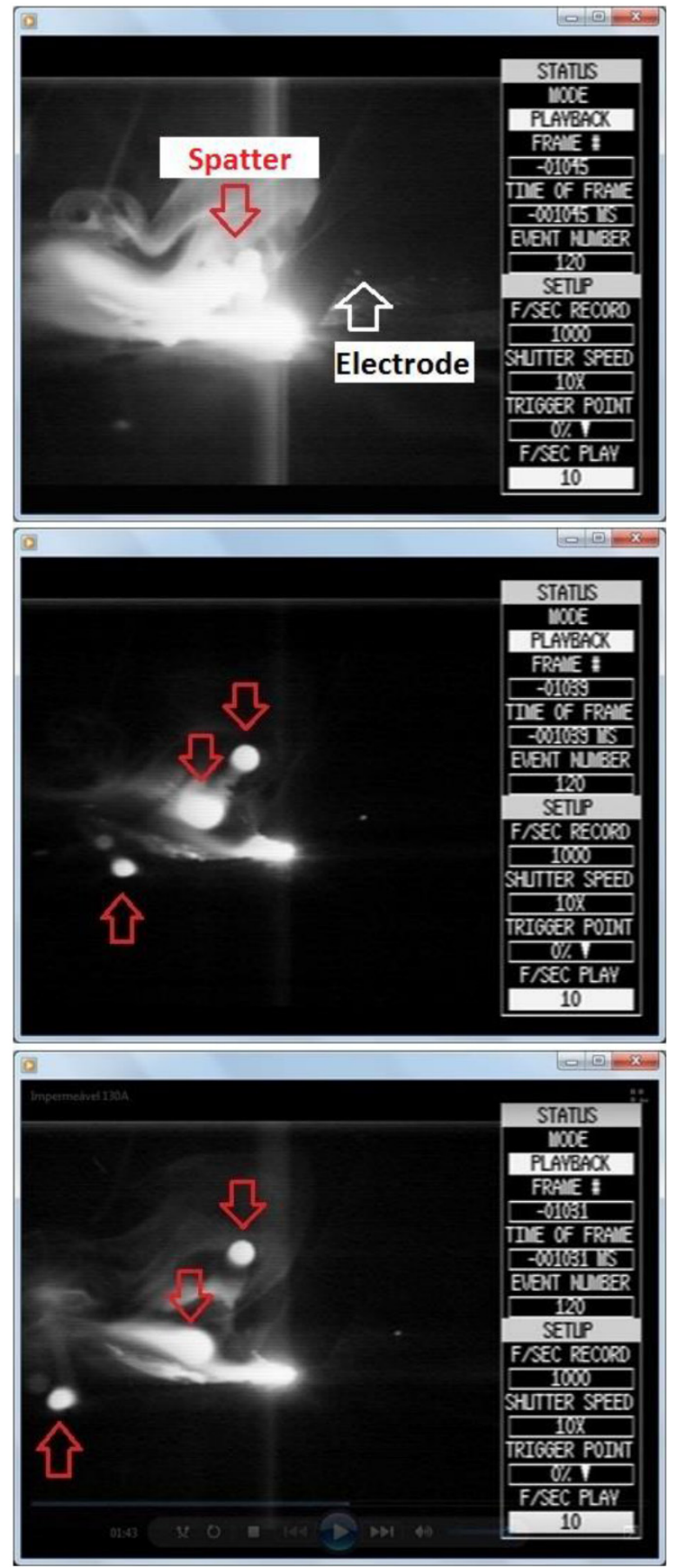

Figure 8. Spatter formation during welding with the polymer-binder electrode at a current of $130 \mathrm{~A}$. Filmed from the side.

The films were also used to determine short-circuit frequency. In the first count, the criterion used to define a short circuit was complete interruption of the electric arc. The results revealed that there was a lower short-circuit frequency for the polymer-binder electrode than indicated by the oscillograms. As voltages below $5 \mathrm{~V}$ were used to characterize a short circuit in the oscillograms, a new criterion was used to analyze the images, and events where there was a reduction in the intensity of the arc without it being completely interrupted were considered short circuits. The graph in Figure 11 shows the consolidated results, from which it can be seen that there are no differences in the values measured using the two techniques regardless of the type of electrode used. In many of 


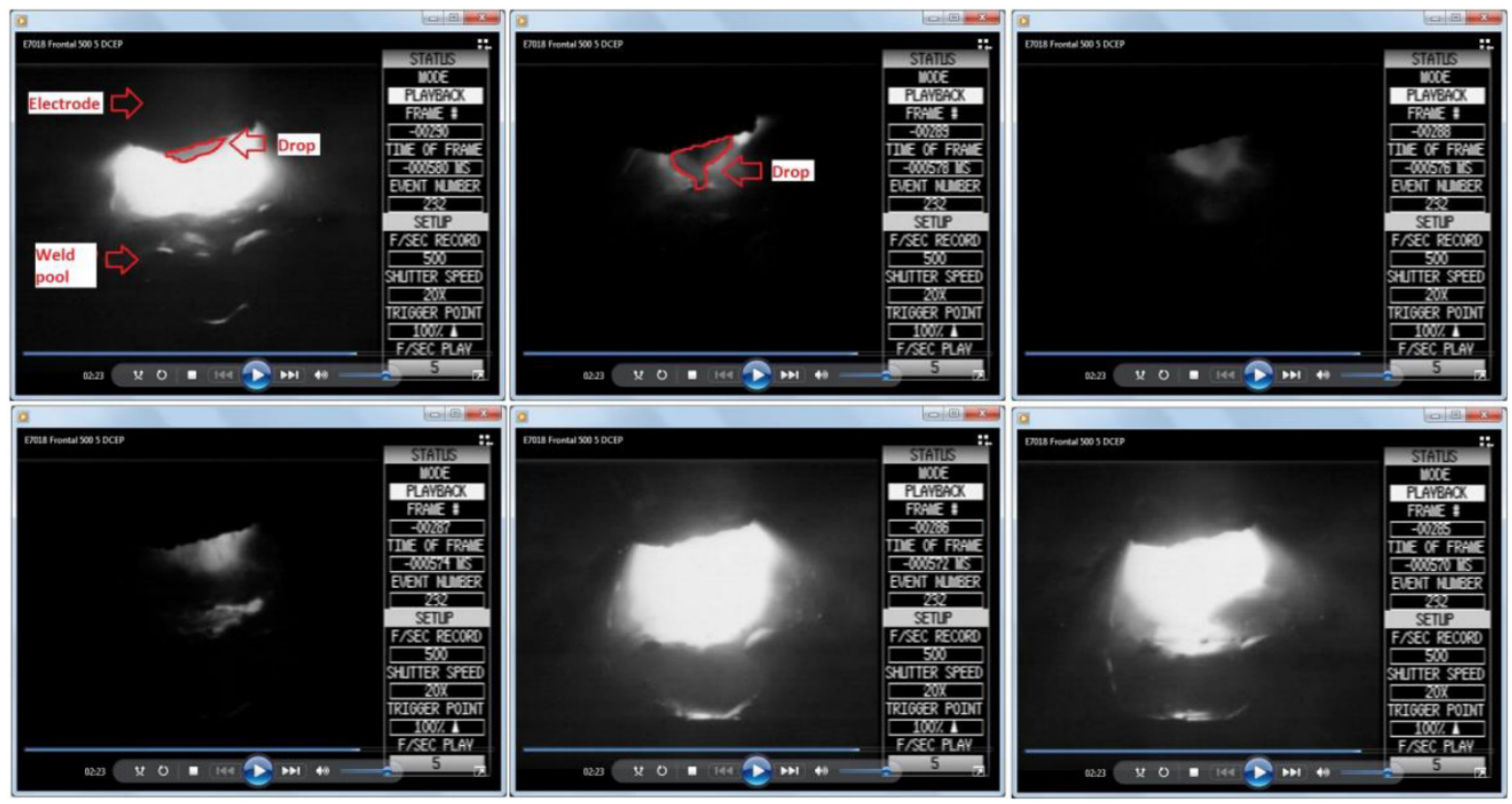

Figure 9. Sequences of images showing metal transfer with the silicate-binder electrode (the drop detaches from the electrode with a short circuit).

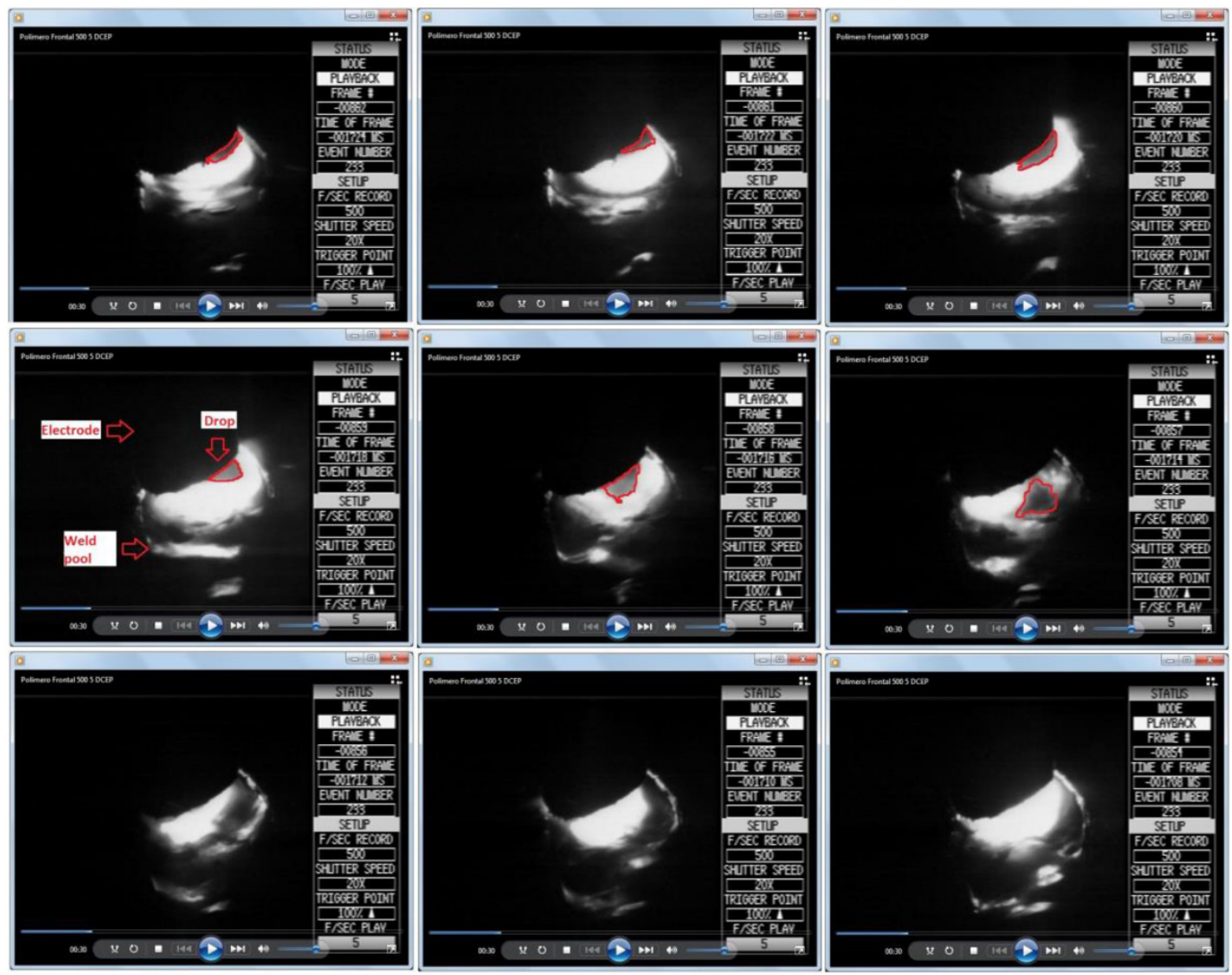

Figure 10. Sequences of images showing metal transfer with the polymer-binder electrode (the drop detaches from the electrode without a short circuit). 
the events observed during welding with the polymer-binder electrode, transfer occurs before the drop makes contact with the weld pool.

The mean size of drops deposited by polymer-binder electrodes was measured by Vaz and Bracarense [4] in a study of the influence of PTFE on the formation of acicular ferrite in weld metal. The results indicated that, on average, the drops produced when polymer-binder consumable is used are smaller than those produced with a silicate-binder electrode. Analysis of the high-speed recordings made in the present study supports the findings reported by Vaz and Bracarense [4].

Figure 12 shows macrographs of cross sections of the electrode tips. Analysis of these appears to show differences in the depth of the coating crater. However, this can be explained by the difference in the morphology of the drops produced when the cores of the electrodes studied here melt. The mosaics in Figure 13 produced from micrographs taken with an optical microscope at $25 \mathrm{x}$ magnification show various geometric characteristics of interest. The red line represents the internal edge of the crater and the white lines the angle between the outer edge of the drop formed and the internal surface of the crater. It can be clearly seen that the angle between the outer edge of the drop and the internal edge of the crater for the polymer-binder electrode is greater than the corresponding angle for the silicate-binder electrode. It can be concluded from these images that the differences

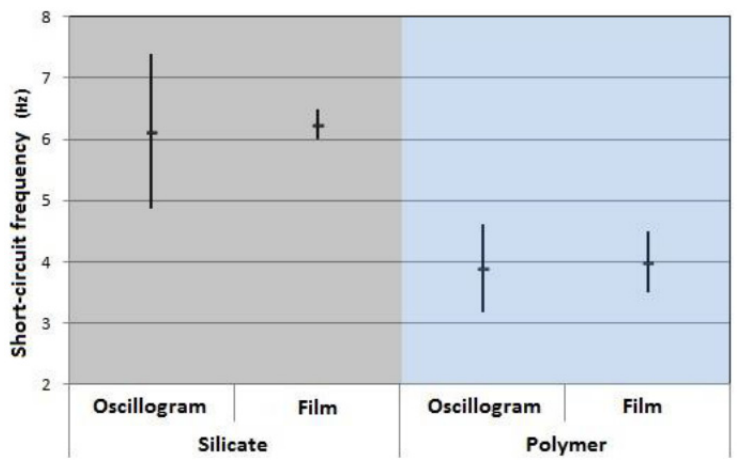

Figure 11. Comparison of short-circuit frequency measured using the oscillograms and using high-speed filming; $95 \%$ confidence interval.
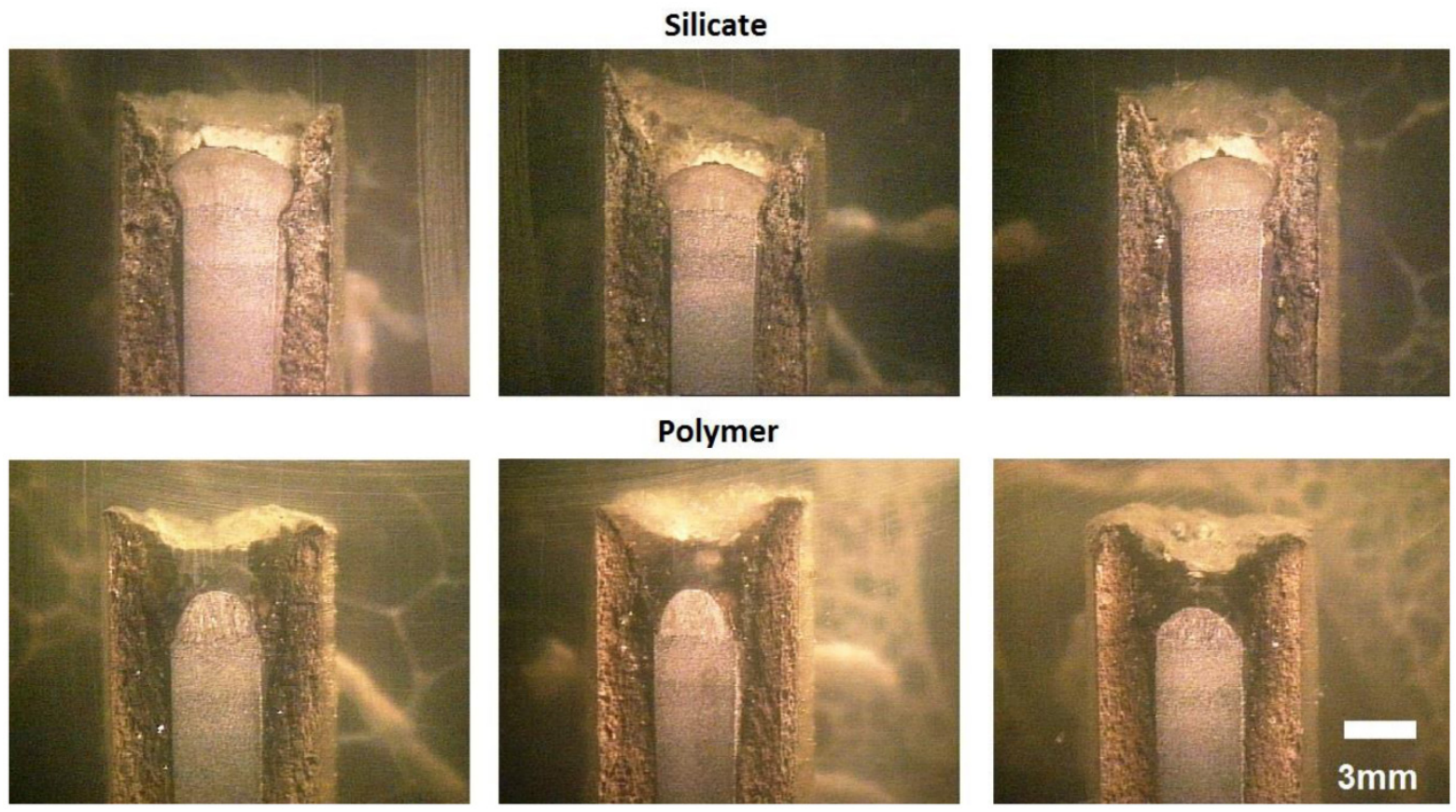

Figure 12. Macrograph of the tips of the polymer-binder and silicate-binder electrodes. 
in the shapes of the drops cannot be attributed to the coating crater. Complementing the experiments, Figure 14 shows micrographs of the cores of the electrodes at different stages during the formation of metal drops. Analysis of these images shows that the drops formed at the tip of the polymer-binder electrode have a tendency to become pinched.

Brandi et al [5] developed a model that showed that the following forces were responsible for metal transfer: surface tension, gravity, electromagnetic force, plasma jet force, vapor pressure and the gas expansion force inside the melted drop. Vaz [9], proposing a model to explain the effect of PTFE on the formation of acicular ferrite, suggests generically that the changes in metal transfer mode observed may be related to changes in the balance between

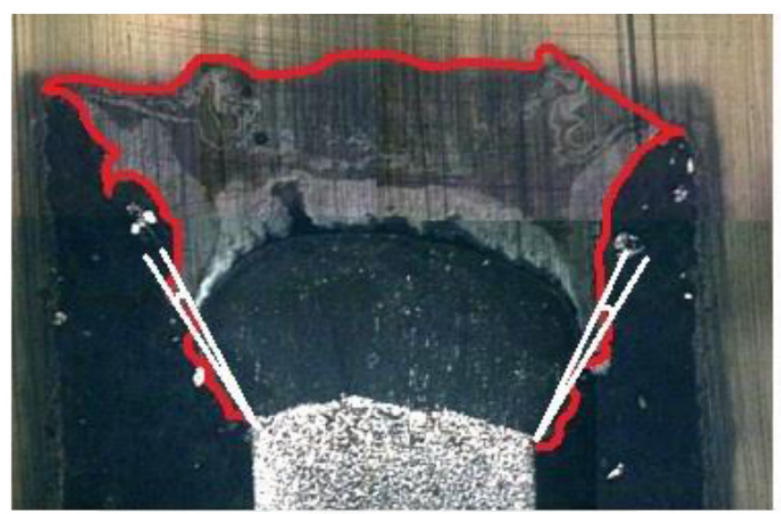

Silicate

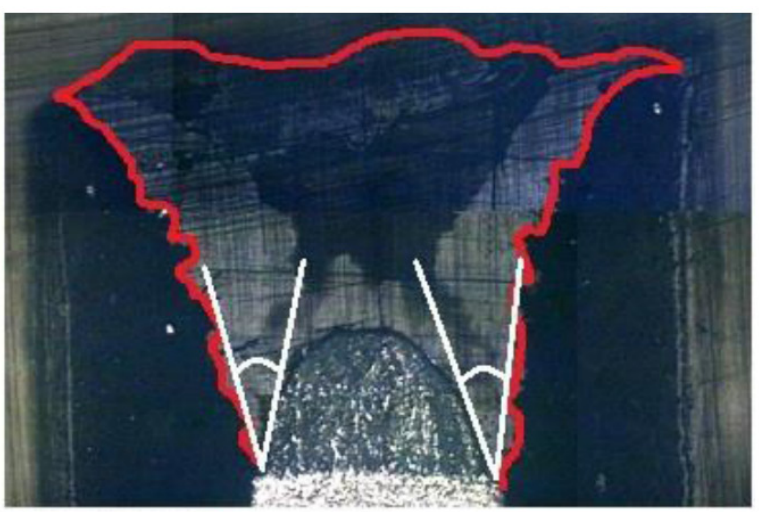

Polymer

Figure 13. Mosaic assembled from optical micrographs at $25 \mathrm{x}$ times magnification. The coating crater is shown in red and the angle between the drop and the internal surface of the crater in white.

\section{Silicate}
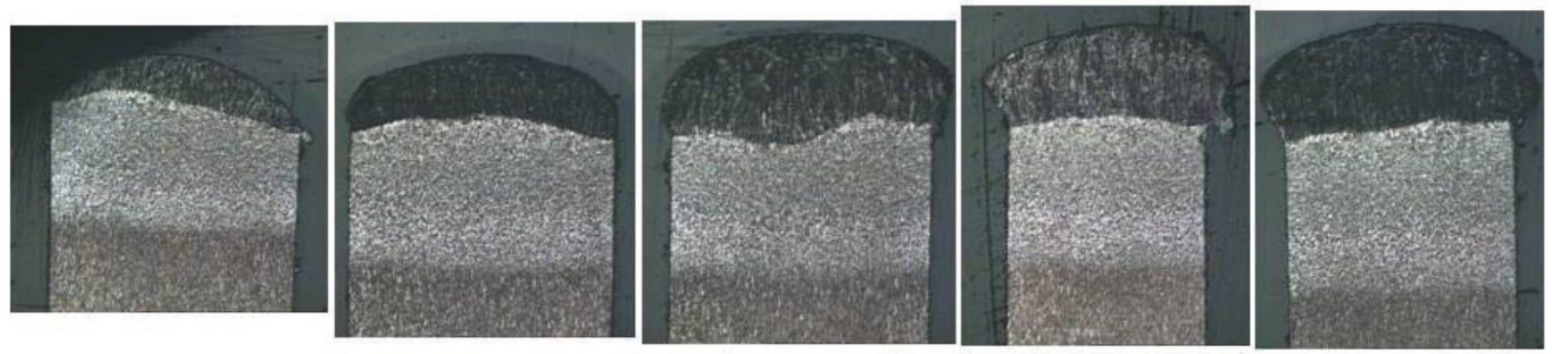

\section{Polymer}
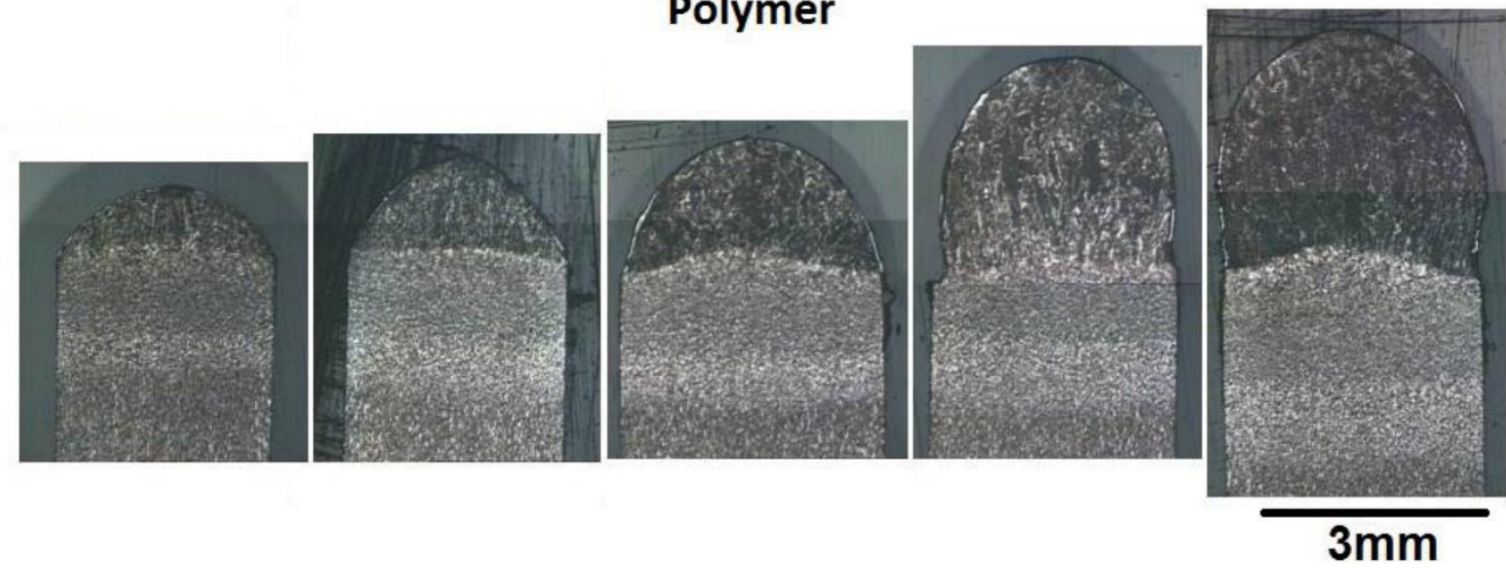

Figure 14. Mosaic of electrode cores assembled from optical micrographs at $25 \mathrm{x}$ magnification showing a drop being formed. Etched with 5\% nital. 
surface tension and the force of the arc. Examination of the results of the present study in light of the studies referred to above suggests that the polymer used as a binder may have altered the surface tension, electromagnetic force and plasma jet. The fact that the angle between the coating crater and the drop is considerably larger for the polymer-binder electrode suggests that the plasma jet has a greater influence with this electrode. However, the pinch effect observed during welding using this electrode indicates that there are also changes in the balance between surface tension and electromagnetic force. Although there are, to the authors' knowledge, no studies that specifically investigate the effect of fluoride ions on the forces responsible for metal transfer, Chen et al [6] reported that an increase in fluorite content in electrode coatings caused an increase in surface tension, making it more difficult for drops to detach from the electrode. Reviewing activated TIG (A-TIG) welding, Modenesi [10] discusses the theories that explain the increased penetration of the bead when fluxes, such as fluorites, are used. The presence of negative ions changes the shape of the bead and the electromagnetic pressure on the arc. This explanation agrees with the increased penetration of the bead observed by Vaz et al [9] in an electrode with a coating to which a polymer had been added. These observations support the hypothesis that there is a change in the balance between surface tension and electromagnetic force that favors the latter.

\section{Conclusions}

The following conclusions can be drawn from the results of this study:

- An increase in current from 90 to $130 \mathrm{~A}$ reduced the short-circuit frequency for both consumables. For the silicate-binder electrode, however, the change was within the limits of measurement uncertainty;

- There was a sudden change in metal transfer mode during welding with the polymer-binder electrode at a current of $130 \mathrm{~A}$. Under these conditions spatter was observed without a short circuit. This result is compatible with explosive transfer;

- High-speed filming showed that there were numerous events during welding with polymer-binder electrodes that were considered short circuits although the electric arc was not actually interrupted. This was confirmed by comparing the short-circuit frequency using oscillograms and high-speed film recordings;

- Metallographic analysis of the electrode tips revealed significant differences in the angle between the drop formed and the coating crater. The greater angle observed with the polymer-binder electrode suggests that the plasma jet produced with this electrode has a greater effect;

- Examination of the drop formed when the polymer-binder electrode melted revealed a narrowing of the drop characteristic of the pinch effect, suggesting that there are changes in the balance between surface tension and electromagnetic force.

\section{Acknowledgements}

The authors would like to thank the Robotics, Welding and Simulation Laboratory (LRSS) at the Federal University of Minas Gerais for providing the facilities needed for the welding and tests carried out in this study.

\section{References}

[1] Bonizewski T. Manual metal arc welding - old process, new developments. Part III: new solution and challenges. The Metallurgist and Materials Technologist. 1979;11(11):697-705.

[2] Sorokin L. Electrodes with plastic coatings for welding low carbon steels. Welding International. 2004;18(3):232-241. http://dx.doi.org/10.1533/wint.2004.3272.

[3] Vaz CT, Bracarense AQ, Felizardo I, Pessoa EC. Impermeable low hydrogen covered electrodes: weld metal, slag and fume evaluation. Journal of Materials Research and Technology. 2012;1(2):64-70. http://dx.doi.org/10.1016/S2238-7854(12)70012-1.

[4] Vaz CT, Bracarense AQ. Influência do uso de PTFE como aglomerante em eletrodos revestidos básicos sobre a formação de ferrita acicular no metal de solda. Soldagem e Inspeção. 2014;19(2):177-189. http://dx.doi.org/10.1590/0104-9224/ SI1902.10.

[5] Brandi S, Taniguchi C, Liu S. Analysis of metal transfer in shielded metal arc welding. Welding Journal. 1991;70:261s-270s.

[6] Chen JH, Fan D, He ZQ, Ye J, Luo YC. A study of the mechanism for globular metal transfer from covered electrodes. Welding Journal. 1989;68(4):145s-150s.

[7] Lancaster JF. Metallurgy of welding. 5th ed. London: Chapman \& Hall; 1993.

[8] Lancaster JF. The physics of welding. 2nd ed. Oxford: Pergamon, 1986. 
[9] Vaz, C.T. Influência do polímero utilizado como aglomerante em eletrodos revestidos básicos sobre a formação de ferrita acicular no metal de solda [doctor thesis]. Belo Horizonte: Universidade Federal de Minas Gerais; 2014.
[10] Modenesi PJ. A química da formação do cordão na soldagem TIG. Soldagem e Inspeção. 2013;18(3):287-300. http://dx.doi. org/10.1590/S0104-92242013000300011. 